\title{
New immune response modulator for poultry
}

\author{
Ludmila Reznichenko* and Aleksandr Gorbach \\ Belgorod State Agricultural University named after V.Y. Gorin, Belgorod, 308503, Russia
}

\begin{abstract}
Wide application of non-specific drugs in veterinary in order to increase general and specific resistance of an organism, to correct immunity, prevent diseases and treat sick animal will allow reducing morbidity and in the long run to increase productivity of animals. Thus, search for effective and inexpensive immune response modulators that may allow reducing the incidence of antibiotic use is a current task that veterinary service is facing nowadays. The goal of this research was to study the influence of immune response modulators onto the organisms of broiler chickens to propose this preparation as an alternative to antibiotics. As a result of the research, it has been established that medicating broiler chickens with Getmik against the background of removing antibacterial preparations from the medical and preventive procedures facilitates increased gains in poultry and improves natural tolerance. Recommendations are given for application of Getmik in broiler farming as an alternative to antibacterial drugs.
\end{abstract}

\section{Introduction}

Currently, intensive development of poultry farming continues, which requires reliable provision of biologically active substances in order to increase productivity integrity.

In the industrial poultry farming, strengthening immune system of birds is very important in order to prevent infectious diseases. In addition, successful growth and development of the young also requires minimal immune response suppression. However, control strategy in the area of immune response suppression is generally based upon vaccination to minimize stress during the growing period. Thus, use of immune stimulants is a solution to improve the operation of the animals' immune system and reduce their susceptibility to infectious diseases [1]. Interrelation between feeding and immune system shall always be the center of attention.

Recently, there have been a significant number of research works dedicated to studying the influence of biologically active substances onto the condition of the immune system. Of special value are the biologicallysources preparations, which are physiological to the organism and are environmentally safe [2,3].

It is commonly held that the problem of immune deficiency in agricultural animals, especially in poultry comes forward when the farms are industrialized and large-scale complexes are created where there is a large concentration of animals within a small territory. This leads to reducing natural tolerance of the organism and appearance of various diseases among the young [4].

There is an active and ongoing discussion on the use of immune response modulators and immune stimulants in poultry farming. The authors assert that the most rational way is application of immune response modulators that in addition to the immune response modulation have additional useful properties (adjuvant, adaptogenic, anti-inflammatory or anti-oxidizing), as well as stimulating growth and development, etc. [5, 6].

Thus, application of environmentally safe and harmless immune response modulators, antiviral preparations on the basis of natural biologically active substances and other similar preparations allows correcting immune response in the broiler stock, thus facilitating gains and livability of the poultry.

Russian experience in applying the preparations increasing natural and specific tolerance of poultry is rather rich, including, primarily various vitamin and mineral complexes, immune response modulators, probiotics and plant-sourced adaptogens $[7,8]$.

It is commonly assumed that all other things being equal (effectiveness, availability, economic gain, etc.) those immune response modulators are preferable that are not only optimizing the immune system, but also have a positive effect onto the organism, depending on its needs [9].

Due to that, a need arose to introduce new highly efficient preparations against immune deficiency into poultry farming; but above all, such preparations shall be safe for birds, humans and environment as a whole [1012].

Thus, we are of the opinion, that Getmik, a heteropolysaccharide of microbial origin is such a preparation.

The goal is to study the influence of Getmic immune response stimulant onto the organism of broiler chickens as an alternative to antibacterial preparations.

The following tasks were involved in attaining the set goal:

- comparing the effectiveness of Getmic and Phosprenyl onto the organism of broiler chicken when

* Corresponding author: reznichenko6531@gmail.com 
antibiotic preparations are excluded from the procedure of animal disease control;

- determining the influence of the preparations onto the natural tolerance of the chickens.

\section{Material and method of analysis}

The commercial experiment was conducted in the Laboratory of Poultry Farming UNIC Agrotekhnopark of the Belgorod State Agricultural University named after V.Ia. Gorin.

The groups were formed on the similarity principle.

Four groups of one-day-old broiler chickens were formed for the experiment, each group consisted of 40 animals. The first group was control, others were experimental groups.

Chickens in groups 3 and 4 received Phosprenyl and Getmik in water.

No antibacterial preparations were used in the experimental groups.

Prosprenyl is a transparent or weakly opalescent solution, colorless or with a yellowish tint; it includes disodium salt of polyprenol phosphates in the amount of $0.4 \%$ and additionally the following auxiliary substances: glycerine - $3.0 \%$, ethanol - $2.9 \%$, Polysorbate- $80-0.25 \%$ and injection water - to $100 \%$.

Getmik is a polysaccharide of microbial origin. The main active ingredients are galaktomannan and fatty acids. Getmik is a hydrocolloid with high molecular mass, thus, its solution forms a highly viscous gel, whose viscosity depends on temperature and concentration.

Hematological indicators were determined by conventional procedures.

Activity of lysozyme in blood serum was determined by nephelometry according to Dorofeichuk [13], phagocytic activity was calculated by counting phagocytic pseudoeosinophils in 100 cells, bactericidal activity of the blood serum was determined according to I.M. Karaput [14]

The data from all the experiments were statistically processed by conventional methods, Student's test was applied (td). Difference between compared values was considered significant if $\mathrm{p} \leq 0.05$

\section{Test results and discussion}

Four groups of one-day-old broiler chickens were formed for the experiment, each group consisted of 40 animals.

The first group is control, while other three are experimental ones. Chickens in the control group were fed a conventional diet with application of all antibacterial preparations (starting from 2-days of age, ciprofloxacin was added to water in the amount of $5 \mathrm{ml}$ per 101 for 5 days; the same preparation was applied again in water solution for 5 days starting from the 20 days of age). No antibacterial preparations were used in the experimental groups.

Starting from the 7th day, chickens of the experimental group 3 received Phosprenyl in water for 10 days, at a rate of $0.05 \mathrm{ml} / \mathrm{kg}$ of live weight; the chickens of the experimental group 4 received Getmik in water at a dose of $0.4 \mathrm{~g} / \mathrm{kg}$ of live weight. Throughout the growing period, the birds were under observation.

The design of the experiment is shown in Table 1.

Table 1. Design of the experiment

\begin{tabular}{|c|c|c|c|}
\hline Groups & $\begin{array}{c}\text { Number } \\
\text { of } \\
\text { animals }\end{array}$ & Preparations used & Dose \\
\hline $1-$ control & 40 & Basic diet (BD) & - \\
\hline $\begin{array}{c}2- \\
\text { experimental }\end{array}$ & 40 & $\begin{array}{c}\text { BD (without } \\
\text { antibacterial } \\
\text { preparations) }\end{array}$ & - \\
\hline $\begin{array}{c}3- \\
\text { experimental }\end{array}$ & 40 & $\begin{array}{c}\text { BD (without } \\
\text { antibacterial } \\
\text { preparations) } \\
\text { Phosprenyl }\end{array}$ & $\begin{array}{c}0.05 \mathrm{ml} / \mathrm{kg} \\
\text { of live } \\
\text { weight }\end{array}$ \\
\hline $\begin{array}{c}4- \\
\text { experimental }\end{array}$ & 40 & $\begin{array}{c}\text { BD (without } \\
\text { antibacterial } \\
\text { preparations) + Getmik }\end{array}$ & $\begin{array}{c}0.4 \mathrm{~g} / \mathrm{kg} \text { of } \\
\text { live weight }\end{array}$ \\
\hline
\end{tabular}

As a result of the research, a positive effect of the studied preparations onto the poultry organism was revealed (Table 2). In the end of the experiment, livability of chickens in the third group (Phosprenyl) and the fourth group (Getmik) amounted to 97.5 and $95 \%$ respectively, while in the control group it was $87.5 \%$ and in the second experimental groups where no antibiotic preparations were used it was just $80.0 \%$. As for daily average gain, the third group showed gains at the same level as control. In the fourth experimental group, the gains were $1.8 \%$ higher than in the control group. In the second group that was raised without antibiotics, average daily gain was $5.7 \%$ lower than in control.

Table 2. Testing results for Phosprenyl and Getmik use in broiler chickens

\begin{tabular}{|c|c|c|c|c|}
\hline \multirow{2}{*}{ Indicators } & \multicolumn{4}{|c|}{ Groups } \\
\hline & $\begin{array}{l}\overline{0} \\
\stackrel{\Xi}{0} \\
0 \\
1 \\
-\end{array}$ & 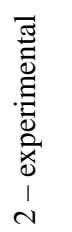 & 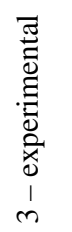 & 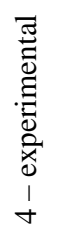 \\
\hline $\begin{array}{l}\text { Number, animals } \\
\text { In the beginning of the } \\
\text { experiment }\end{array}$ & 40 & 40 & 40 & 40 \\
\hline in the end of the experiment & 35 & 32 & 39 & 38 \\
\hline Livability, \% & 87.5 & 80.0 & 97.5 & 95 \\
\hline Daily live weight gain, $g$ & 65 & 61.3 & 64.8 & 66.2 \\
\hline \pm to control, $\%$ & - & -5.7 & -0.3 & +1.8 \\
\hline $\begin{array}{l}\text { Feed expense per } 1 \mathrm{~kg} \text { of live } \\
\text { weight gain, } \mathrm{kg}\end{array}$ & 1.82 & 1.86 & 1.81 & 1.80 \\
\hline \pm to control, $\%$ & - & +2.1 & -0.5 & -1.1 \\
\hline
\end{tabular}

Thus, the experiment demonstrated a possibility to exclude antibacterial preparations from the animal disease control, on condition of using Phosprenyl in the amount of $0.05 \mathrm{ml} / \mathrm{kg}$ of live weight and Getmik at a dose of $0.4 \mathrm{~g} / \mathrm{kg}$ of live weight.

Biochemical and morphological composition of blood are shown in Tables 3 and 4. 
Table 3. Biochemical parameters of broiler chicken blood $n=20(M \pm m)$

\begin{tabular}{|c|c|c|c|c|}
\hline \multirow[b]{3}{*}{ Indicators } & \multicolumn{4}{|c|}{ Groups } \\
\hline & $1-$ Control & 2 - experimental & 3 - experimental & 4 - experimental \\
\hline & $\mathrm{BD}$ & $\begin{array}{l}\mathrm{BD} \text { ((without } \\
\text { antibacterial } \\
\text { preparations) }\end{array}$ & $\begin{array}{c}\mathrm{BD}((\text { without } \\
\text { antibacterial } \\
\text { preparations })+ \\
\text { Phosprenyl }\end{array}$ & $\begin{array}{l}\text { BD ((without } \\
\text { antibacterial } \\
\text { preparations })) \\
\text { +Getmik }\end{array}$ \\
\hline Total protein, $\mathrm{g} / \mathrm{l}$ & $46.2 \pm 1.22$ & $45.7 \pm 1.30$ & $48.1 \pm 1.54$ & $48.6 \pm 1.22$ \\
\hline Albumens, \% & $41.6 \pm 1.20$ & $41.8 \pm 1.27$ & $38.4 \pm 1.26$ & $38.3 \pm 1.27$ \\
\hline$\alpha$-globulins, $\%$ & $17.4 \pm 1.32$ & $17.9 \pm 1.54$ & $16.3 \pm 1.47$ & $16.6 \pm 1.54$ \\
\hline$\beta$-globulins, \% & $15.6 \pm 0.53$ & $16.2 \pm 0.65$ & $17.4 \pm 0.50 *$ & $17.1 \pm 0.49 *$ \\
\hline$\gamma$-globulins, $\%$ & $25.4 \pm 0.69$ & $24.1 \pm 0.67$ & $27.9 \pm 0.71 *$ & $28.0 \pm 0.70 *$ \\
\hline Calcium, $\mathrm{mmol} / \mathrm{l}$ & $3.57 \pm 0.65$ & $3.43 \pm 0.60$ & $4.22 \pm 0.53$ & $4.37 \pm 0.68$ \\
\hline Phosphorus, $\mathrm{mmol} / \mathrm{l}$ & $2.21 \pm 0.27$ & $2.43 \pm 0.32$ & $2.03 \pm 0.39$ & $2.12 \pm 0.42$ \\
\hline Cholesterol, $\mathrm{mmol} / \mathrm{l}$ & $1.48 \pm 0.33$ & $1.47 \pm 0.34$ & $1.42 \pm 0.41$ & $1.46 \pm 0.38$ \\
\hline Urea, $\mathrm{mmol} / \mathrm{l}$ & $0.92 \pm 0.09$ & $0.94 \pm 0.06$ & $0.95 \pm 0.08$ & $0.88 \pm 0.12$ \\
\hline Glucose, $\mathrm{mmol} / \mathrm{l}$ & $15.7 \pm 0.62$ & $14.8 \pm 0.63$ & $16.2 \pm 0.79$ & $17.9 \pm 0.58 *$ \\
\hline
\end{tabular}

Note: - * p $<0.05$

The data in the table shows that after application of the preparations, protein content in blood serum in all the experimental groups was at the same level as in the control group. As for protein fractions, there were some differences. For instance, in the third and the fourth experimental groups, after application of Phosprenyl and Getmic, the level of albumens underwent insignificant reduction by 7.7 and $7.9 \%$ respectively, while the amount of $\alpha$-globulins reduced by 6.3 and $4.6 \%$, however in both cases the difference with the control group fails the statistical significance test $(p>0,05)$.

A statistically significant increase in $\beta$-globulins with respect to control values is of notion, in the third experimental group it amounted to $11.5 \%$, in the fourth experimental group it amounted to $9.6 \%$. The same is true for $\gamma$-globulins, in the third experimental group their content increased by $9.8 \%$, in the fourth experimental group it increased by $9.6 \%$. In these cases, $\mathrm{p}<0.05$.

It is known that the molecules of $\beta$-globulins fix carbohydrates, vitamins, hormones, enzymes, various metabolic products from cell death and harmful substances entering the organism. $\beta$-globulins are linked to group factors of blood and complement. A number of proteins of this fraction form a part of the blood coagulation system. Thus, increase in this protein fraction shall be considered a positive effect of the studied preparations.

Physiological role of $\gamma$-globulins is primarily related to immunological processes, as they include the main body of antibodies. Antibodies present in the blood serum continuously participate in the non-specific protection of the organism. They are formed as a normal component of the serum, not as a response to stimulus from a pathogenic microorganism.

Thus, it may be assumed that the studied preparations participate in stimulation of the immune system of the organism.

Certain specificity of $\gamma$-globulins in animals that were not affected by antigens is most probably related to reaction to antigens introduced through wounds, mouth, digestive and respiratory tracts. This function of $\gamma$ globulins is called a transport function.

The level of calcium in the blood serum of chickens from groups 3 and 4 had a trend to an increase, while phosphorus trended to a decrease, but in both cases, the difference with the control group was not deemed statistically significant.

Cholesterol and urea content in all the experimental groups differed from control insignificantly. As for glucose, its level reliably increased in the group 4 after application of Getmik (by $14 \%, \mathrm{p}<0.05$ ), witnessing to stimulation of carbohydrate metabolism.

From the data, it is evident that the use of Phosprenyl and Getmic caused a statistically significant increase in leukocyte count in the blood of broiler chickens in the 3rd and 4th experimental groups (by 18.9 and $19.7 \%$ respectively, at $\mathrm{p}<0.05)$. These changes shall be considered positive, witnessing to strengthened protection of the organism, at this increase is within the physiological norm.

It should be noted that there is also increased hemoglobin level in the blood of chickens from experimental groups 3 and 4 , at that the difference is statistically significant only for Phosprenyl (by $14.4 \%$, at $\mathrm{p}<0.05$ ).

Erythrocyte count in the experimental groups 3 and 4 showed no practical difference with the control. However, in the experimental group 2 where no antibiotics were used there was a reduction of $29.4 \%$ observed. At that, the difference with control is statistically significant $(p<0.05)$. This indicator is witnessing to disruption of blood circulation. This condition may appear due to insufficient production of blood cells by bone marrow, or due to destruction of erythrocytes during their movement through capillaries. Reduction in erythrocyte count is often in deficiency microelements, Vitamin $\mathrm{B}_{12}$ and iron.

Indicators of natural tolerance are given in Table 5 .

* Corresponding author: reznichenko6531@gmail.com 
Antibody response of the organism is indicated by lysozyme and bactericidal activity of the blood serum, the state of cell factors of immunity are shown bey phagocytic activity of pseudoeosinophils.

Table 4. Morphological composition of broiler chicken blood $n=20(M \pm m)$

\begin{tabular}{|c|c|c|c|}
\hline \multirow{2}{*}{ Groups } & \multicolumn{3}{|c|}{ Indicators } \\
\cline { 2 - 4 } & Eritrotsita, $10^{12} / l$ & Leukocytes, $10^{9} / l$ & Hemoglobin, $g / l$ \\
\hline 1 - control BD & $3.50 \pm 0.27$ & $30.16 \pm 1.66$ & $98.22 \pm 3.49$ \\
\hline $\begin{array}{c}2 \text { - experimental, BD ((without } \\
\text { antibacterial preparations) }\end{array}$ & $2.47 \pm 0.31^{*}$ & $31.22 \pm 1.89$ & $112.37 \pm 3.26$ \\
\hline $\begin{array}{c}3-\text { experimental, BD (without } \\
\text { antibacterial preparations) } \\
\text { Phosprenyl }\end{array}$ & $3.54 \pm 0.67$ & $35.88 \pm 1.64^{*}$ & $106.21 \pm 3.50$ \\
\hline $\begin{array}{c}4-\text { experimental, BD ((without } \\
\text { antibacterial preparations)+ } \\
\text { Getmik }\end{array}$ & $3.62 \pm 0.51$ & $36.10 \pm 1.72^{*}$ & \\
\hline
\end{tabular}

Table 5. Natural tolerance indicators of broiler chickens $\mathrm{n}=20(\mathrm{M} \pm \mathrm{m})$

\begin{tabular}{|c|c|c|c|c|}
\hline \multirow{2}{*}{ Indicators } & \multicolumn{3}{|c|}{ Groups } \\
\cline { 2 - 5 } & $1-$ control & 2 - experimental & 3 - experimental & $4-$ experimental \\
\hline Bactericidal activity, \% & $34.26 \pm 1.52$ & $33.47 \pm 1.76$ & $39.87 \pm 1.50^{*}$ & $40.13 \pm 1.54 *$ \\
\hline Lysosomal activity, \% & $12.27 \pm 1.19$ & $11.14 \pm 1.26$ & $12.68 \pm 1.37$ & $12.79 \pm 1.76$ \\
\hline Phagocytic activity, \% & $36.47 \pm 2.14$ & $35.18 \pm 1.98$ & $38.25 \pm 1.76$ & $39.10 \pm 1.93$ \\
\hline
\end{tabular}
$*-\mathrm{p}<0.05$

The data shown in the table demonstrates that use of the preparations had no detrimental effect onto indicators of natural tolerance of the animals. It should be noted, that in experimental groups 3 and 4, where Phosprenyl and Getmik were used against the background of removing antibacterial preparation, there is a statistically significant increase in bactericidal activity of the blood serum, by 16.3 and $17.5 \%$ respectively, at $p<0,05$.

In the same groups, phagocytic activity of leukocytes was increased, and while the difference was deemed statistically insignificant, it should be considered a positive trend.

In the experimental group 2, where no antibacterial preparations were used, no studied indicators had significant difference from the controls.

Thus, the research has shown that both studied preparations increase the natural tolerance of the organism against the background of dechallanging antibiotics, leading to increased average daily gains and livability of poultry.

\section{Conclusion}

Immune response modulator Getmik is proposed as an alternative to antibacterial preparations in broiler chicken farming. The preparation is recommended to be used with water, at a rate of $0.4 \mathrm{~g} / \mathrm{kg}$ of live weight for 10 days starting from the age of 7 days.

\section{References}

1. L.V. Reznichenko, A.A. Gorbach, A.A. Reznichenko, Mater. of the International Conf. Scientific research of the SCO countries: synergy and integration (Beijing, China, 2019)

2. L. Reznichenko, O. Bykova, F. Denisova, A. Manokhin, S. Vodyanitskaia, Int. J. of Advan. Biotechnol. and Res. (IJABR), 10(2), 560-566 (2019)

3. R.Ya. Gilmutdinov, A.M. Alimov, G.F. Kabirov, F.A. Medetkhanov et al., Res. J. of Pharmac., Biol. and Chem. Sci. (RJPBCS), 9(6), 1156-1160 (November-December 2018)

4. Iu.V. Konopatov, E.E. Makeeva, Foundations of Immunity and Poultry Feeding (St. Petersburg, 2000) p. 75

5. I.I. Kochish, Poultry Farm., 25-31 (2007)

6. R.V. Ulyanov, I.Iu. Domnitsky, A.A. Sazonov, S.V. Novikova, Modern Issues in Veterinary Oncology and Immunology: Mater. of Int. Sci. Pract. Conf. Coll. Sci. reports (Nauka, Saratov, 2014) pp. 245248

7. M.I. Podchalimov, E.M. Gribanova, Poultry, 8, 25-28 (2012)

8. S.V. Shabunin, V.N. Dolgopolov, Poultry, 8, 42-48 (2014)

9. A.A. Reznichenko, Conf. on Agribusiness, Environmental Engineering and Biotechnologies (AGRITECH-2019) (2019) p. 50 
10. N.M. Kazachkova, S.R. Ishbulatova, G.K. Duskaev, Int. Student Sci. Herald, 4-3 (2017)

11. L.N. Skvortsova, Reports of the Russ. Acad. of Agricult. Sci., 3, 38-40 (2010)

12. R.I. Castillo-Lypez, E.P. Gutiérrez-Grijalva, N. Leyva-López et al., Plant Sci., 27(2), 349-359 (2017)
13. V.G. Dorofeichuk, Determination of lysozyme activity by nephelometry, Laboratory Work, 1, 2830 (1968)

14. I.M. Karput, Immunology and immunopathology of diseases of the young (Uradzhay, Minsk, 1993) 